PAAVO RAVILA

\title{
Adjektiiviattribuutin kongruenssin synty suomen kielessä
}

Suomalais-ugrilaisissa kielissä on yleisenä sääntönä se, että. adjektiiviattribuutti esiintyy taipumattomana pääsanansa edessä. Vallitsevan käsityksen mukaan tämä on kantakielen perintöä. Oikeastaan vain itämerensuomalaiset kielet muodostavat poikkeuksen. Tutkijoita on ymmärrettäristä syistä jo kauan askarruttanut kysymys, mikä on tuonut kongruenssin suomeen ja sen lähimpiin sukukieliin. Kun on ollut peräti vaikeata nähdä, mikä seikka itse kielen rakenteessa nimenomaan itämerensuomalaisella taholla olisi antanut sysäyksen ilmiön syntymiselle, niin on ollut lähellä se ajatus, että. indoeurooppalainen vaikutus on näytellyt ratkiaisevaa osaa. Monet tutkijat, sekä suomalaiset että unkarilaiset, ovat pitäneet sekä balttilaista että germaanista vaikutusta mahdollisena. Irén SebestyénNémeth on nuoruudenaikaisessa tutkimuksessaan niin ikään assettunut tälle kannalle, mutta hän on kuitenkin tahtonut nähdä itämerensuomalaisissa kielissä eräitä ilmiöitä, jotka voisivat viitata siilen, että kotoinen maaperä jo sinänsä oli otollinen vierasta vaikutusta vastaanottamaan. Tällaisia tapauksia ovat hänen mukaansa nimenomaan ne, joissa attribuutti saattaa esiintyä pääsanansa jäljessä ja joita varsinkin vanha kansanrunoutemme tuntee. Näiden rivien kirjoittaja on myös pitänyt indoeurooppalaista vaikutusta mahdollisena. Olen kuitenkin viitannut eräisiin lapissa, mordvassa ja samojedissa tavattaviin ilmiöihin, jotka osoittavat kongruenssin ituja esiintyvän kieliperheemme piirissä muuallakin. Näitä ituja en kuitenkaan ole voinut saattaa elimelliseen yhteyteen oman kielemme kongruenssin kanssa.

On kuitenkin kuulunut hyvinkin varteenotettavia mielipiteitä, että kongruenssi olisikin itämerensuomalaisissa kielissä käsitettävä. 
kokonaan omapohjaiseksi ilmiöksi. Sinänsä tämä ei olisikaan outoa, sillä kongruenssin siemen on itse asiassa kylvetty sillä hetkellä, jolloin taivutus on syntynyt. Kongruenssimme alku onkin selitetty periaatteessa samalla tavalla kuin indoeurooppalaisella alalla on tehty. Niinpä Hermann Paul esim. sanoo, että kaasuskongruenssi on syntynyt appositioasemassa. Tämä toteamus pitääkin ilmeisesti paikkansa mitä erilaisimpiin kieliin nähden, joten sillä on tietynlainen yleispätevyys. Ansiokkaassa käsikirjassaan Lauri Hakulinen sanoo: "Varsin todennäköiseltä tuntuukin, että adjektiiviattribuutin taivutuksellinen pääsanaansa mukautuminen on saanut syntysysäyksensä apposition luonteisesta adjektiivin käytöstä. On sanottu sekä

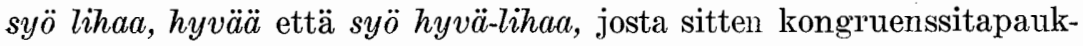
set ovat syntyneet kontaminaation kautta." Tällaista selitystä vastaan' voidaan tietysti huomauttaa, että on vaikeata esittää mitään vakuuttavia todisteita siitä, että adjektiivin käyttö appositiona pääsanansa jäljessä todella olisi ollut niin yleistä ja niin vanhaa perua, että se olisi voinut vaikuttaa pääsanan edellä olevaan attribuuttiin näin merkittävällä tavalla. Wolfgang Schlachter on tämäntapaisen huomautuksen tehnyt eräässä v. 1958 ilmestyneessä kirjoitelmassaan ja Hakulinen onkin teoksensa saksankielisessä laitoksessa kiinnittänyt siihen huomiota. Schlachter päätyy siihen tulokseen, että indoeurooppalainen vaikutus on edelleen otettava huomioon. Hänen esityksensä sisältää useita mielenkiintoisia näkökohtia, mutta en puutu tässä yhteydessä niihin. Huomautan vain, että hänen mielestään sellaiset tapaukset kuin suuressa talossani, jossa possessiivisuffiksi ei esiinny attribuutissa, puhuu lainasuhteen puolesta paremminkin kuin kontaminaatioajatuksen. Olisihan suorastaan odotuksenmukaista, että possessiivisuffiksi esiintyisi appositiossa ja sen vaikutuksesta sitten attribuutissakin. Germaanisella taholla ei taas possessiivisuffiksisysteemiä tunneta lainkaan, niin että suomen kongruenssissa esiintyvä aukko voisi hyvinkin selittyä juuri tästä.

I. Sebestyén-Németh on äskettäin palannut uudelleen nuoruutensa aiheeseen. Hän on kiinnittänyt huomionsa erityisesti samojediin ja on ollut löytävinään sieltä selityksen avaimen. Samojedissa esiintyy runsaasti tapauksia, joissa possessiivisuffiksi liittyy sekä attribuuttiin että pääsanaan, esim. (Castrén) muatau teu 'das von mir gehaltene Rentier', mueundau nieu 'das Weib, welches ich nehmen sollte', (Lehtisalo) šid'á $\beta$ pū $\bar{u} \beta$ 'meine zwei frauen'. On van- 
hastaan tunnettu asia, että samojedissa samoin kuin monissa suomalais-ugrilaisissa kielissä käytetään possessiivisuffikseja determinoivassa funktiossa. Kongruenssi juontaakin Sebestyénin mukaan alkunsa possessiivisuffiksin laajentuneesta ja lauseen varsinaiseen merkitykseen vaikuttamattomasta käytöstä. Tällaisista funktioista. on kongruenssi sitten analogian tietä päässyt yleistymään sellaisiinkin tapauksiin, joissa attribuutti saa saman kaasuspäätteen tai numerusmerkin kuin pääsana. Venäläisen samojedin tuntijan Tereščenkon mukaan Bolšaja Zemljan murteessa tavataan attribuutin numeruskongruenssia nominatiivissa ja akkusatiivissa, osittain myös genetiivissä ja prosekutiivissä. Yleensähän samojedissa ei ole kongruenssia, sillä myös lukusana esiintyy säännöllisesti taipumattomana pääsanan edessä. Toivosen ajatusten innoittamana Sebestyén selittää, että kongruenssi on aivan samalla tavalla kuin astevaihtelukin kulkeutunut itämerensuomalaisiin kieliin samojedilaiskieliin kuuluneen protolapin vaikutuksesta. Kun mordvastakin on todettu eräitä vähäisiä kongruenssitapauksia, on tämä ymmärrettävä niin ikään Toivosen tapaan siten, että protolappi on muuttunut varsinaiseksi suomalais-ugrilaiseksi kieleksi jo suomalais-volgalaisena kautena. Selityksen heikkona kohtana on tietenkin se, että lapissa, joka olisi varsinaisesti kongruenssin aiheuttanut, ei sellaista kongruenssia kuin suomessa tavata. Sebestyén selviytyy tästä sillä tavoin, että hän katsoo samojedilaisvaikutuksen tehostaneen eräitä suomessa esiintyneitä tendenssejä. Itse asiassa hänen teoriansa ei näin ollen ole suurestikaan muuttunut nuoruudenaikaisesta. Balttilaisen ja germaanisen vaikutuksen tilalle on nyt tullut samojedin vaikutus. Hänen mukaansa suomen kielessä jo ikivanhoina aikoina taipumaton attribuutti saattoi esiintyä joko pääsanan edessä tai jäljessä, sanottiin siis joko suuri talossa tai talossa suuri. Tämän rinnalla oli sitä paitsi appositionaalista käyttöä: talossa suuressa. Samojedilaisvaikutus kohdistui ensi sijassa niihin attribuuttikonstruktioihin, joissa sananjärjestys oli tavallisuudesta poikkeava ja tätä vaikutusta oli tietenkin appositiorakenne tukemassa. Luulen, että kritiikin ei ole syytä lähemmin puuttua samojedihypoteesiin, sillä se on yhtälö, jossa on pelkkiä tuntemattomia. Irén Sebestyén-Németh on kuitenkin tehnyt tịeteelle suuren palveluksen keräämällä runsaasti mielenkiintoista ainestà samojedikielistä. Se luo joka tapauksessa käsitykseni mukaan hụomattavaa valaisua kongruenssin muodostumisongelmaan. 
Sebestyén toteaa, että esim. akkusatiivin $m$ saattaa usein liittyä sekä attribuuttiin että pääsanaan, esim. tjikīm gāsauam 'diesen Mann', jū $d m$ gālem amamsi 'zehn Fische ass ich', njābim bīriptjem 'eine andere Fungfrau', sauam sieam nimsi $h \bar{o}$ ' oh 'eine gute Übernachtungstelle fand ich nicht'. Ei voi välttyä huomaamasta, että. Sebestyénin esimerkeistä valtaosa on tapauksia, joissa attribuuttina. on pronomini tai lukusana. Tämä tuo mieleen ilman muuta sen seikan, että lapissa tavataan kongruenssia vain silloin, kun attribuuttina on pronomini tai lukusana. Sitä paitsi adjektiivit hyvä ja paha kongruoivat. Mordvassakin esiintyy hyvä sanan yhteydessä numeruskongruenssia. Pronominin ja arvattavasti myös numeraalin kongruenssissa on kysymys vanhoista ilmiöistä ja käsitykseni mukaan nämä tapaukset ovat suorastaan avainasemassa. Ennen kuin lähemmin perustelen omaa teoriaani, on syytä tarkastella lapin suhteita. Lapin kielen asema itämerensuomalaisten kielten lähimpänä sukulaisena pakottaa jo ilman muuta pitämään silmällä sitä mahdollisuutta, että lapin kielen alkeellisella ja suomen kielen kehittyneellä. kongruenssilla on yhteinen lähtökohta.

Ruijanlapissa tapaamme itse asiassa varsin oudolta tuntuvat. kongruenssisuhteet: monikossa on suurin piirtein täydellinen mukautuminen, kun sen sijaan yksikössä useimmissa obliikvisijoissa. attribuutti esiintyy genetiivi-akkusatiivissa, siis seuraavaan tapaan:

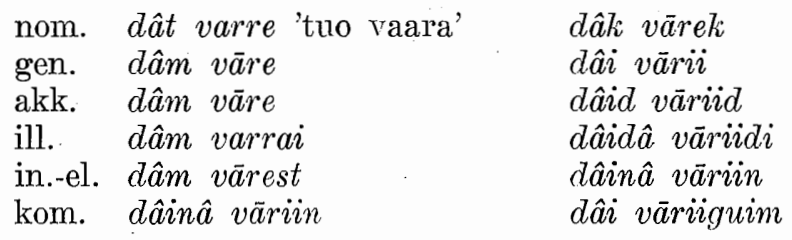

Ei ole mitään aihetta pitää ruijanlappalaista edustusta alkuperäisenä. Olisikin perin vaikeata ymmärtää, miten tällaiset suhteet olisi siinä tapauksessa selitettävä. Kongruenssi on ilmeisesti kantalapissa ollut täydéllisempi ja ruijanlapin järjestelmä taas tästä kehittynyt. Etelälapissa orat ilmeisesti kantalapin suhteet säilyneet varsin hyvin. Bergslandin mukaan voimme esittää seuraavan mallin:

nom. dihty goatie

gen. dân goaitien

akk. dâm goåtiem 
$\begin{array}{ll}\text { ill. } & \text { dân goaitan } \\ \text { iness. dännie goåtasn } \\ \text { elat. dähtie goåtəsto } \\ \text { kom. däjnie goaitańa }\end{array}$

Samoin kongruoi lukusana kuitenkin poikkeuksena se, että akkusatiivi on kuten ruijanlapissakin nominatiivin kaltainen, esim. iness. $g_{<}$ekt’ańa goåt’asn, elat. $g_{<}$elkt’áa goât'ast'a. Kongruenssi on siis täydellinen. Tosin attribuutissa ei ole joka tapauksessa samaa päätéttä kuin pääsanassa, mutta kuitenkin samaa funktiota suorittava pääte. Mielenkiintoista on nyt todeta, että attribuutissa esiintyvät inessiivinä ja elatiivina ikivanhat yksinkertaiset paikallissijojen päätteet, nim. lokatiivin * ${ }^{*}$ a ja ablatiivin ${ }^{*}$ ta. Miten on sitten ruijanlapin "edustus ymmärrettävä kaiken tämän valossa? Luulen, että J. Beronka on lauseopillisissa tutkimuksissaan viitannut oikeille jäljille. On ilmeistä, että illatiivissakin on sanıaan tapaan kuin inessiivissä ja elatiivissa attribuutissa esiintynyt vanha yksinkertaisen paikalFissijàn, tässä tapauksessa siis latiivin pääte. Se on syystä tai toisesta sattunut yhteen genetiivin kanssa, niin kuin jo Wiklund on aikoinaan esittänyt. Kun sitten ruijanlapissa inessiivi $s n>s t$ muutoksen kautta tuli samanlaiseksi kuin elatiivi, niin se ei voinut olla vaikuttamatta attribuuttiinkin, mistä on hyvänä osoituksena eri talioilla tavattava horjuvuus. Genetiivi saattoi näissä oloissa helposti tunkeutua inessiivi-elatiiviin, varsinkin kun se, kuten äsken todettiin, esiintyi jo illatiivissakin.

Ei ole varmaankaan suomen kielen taitajalta jäänyt huomaamatta, että lapissa on sääntönä sellainen taivutus kuin suomessa eräässä yksinäisessä tapauksessa, nim. siinä talossa ja siitä talosta. Näissähän pronomineissa ei ole sekundäärisiä päätteitä, vaan alkuperäiset yksinkertaiset olo- ja erosijan päätteet. Eroa on olemassa kuitenkin, sillä siin $\ddot{a}$ ja siitä ovat varsinaisia inessiivin ja elatiivin muotoja silloinkin kun pronomini esiintyy yksinään. Etelälapissa pronominit ja lukusanat ovat säilyttäneet vanhat sijamuodot vain attribuuttina esiintyessään. Ollessaan yksinään ne taipuvat samoin kuin substantiivit, vrt. esim. (Bergsland) dašnie jih duńniie goåt’sn 'täällä ja tuossa kodassa' (her i huset och borte i gårda), mutta däńíe bieləsn - duñie bielasn 'tällä puolella - tuolla puolella'.

On ilmeistä, että kongruenssi on varsin vanhaa perua, mutta miten ja minkälaisissa oloissa se on syntynyt? On vaikea ajatella 
sellaista ratkaisua, että kaasuspääte olisi tunkeutunut attribuuttiin pääsanasta aikana, jolloin substantiivienkin taivutuksessa yksinkertaiset kaasuspäätteet olivat vielä yleisiä, siis aikana, jolloin sanottiin esim. tänä kotana. Miksi päätteen kongruenssi olisi rajoittunut vain pronominaali- ja numeraaliattribuuttiin? Tämä on kysymyksen ydin, sillä attribuuttikongruenssin alkua on etsittävä nimenomaan pronominitapauksista, ovathan ne ainoat, joissa eri tahoilla uralilaisissa kielissä tavataan yhtäpitävyyttä.. On'syytä muistaa myös tässä yhteydessä unkarin tunnetut tapaukset ezt a házat, ebben a házban, jotka nähdäkseni ovat erittäin tärkeitä pronominaalikongruenssin syntyä selvitettäessä.

Uralilaisessa kantakielessä on sanajärjestys ollut hyvin tiukka, attribuutti on ollut pääsanansa edessä. Vasta taivutussysteemin kehityttyä yhä täydellisemmäksi, kongruenssin synnyttyä ja vieraiden kielten vaikutuksesta on eri tahoilla havaittavissa poikkeuksia. Kuitenkin on pakko todeta, että sanajärjestyksen suuri pääsääntö ei ole pätenyt kantakielessä kaikissa tapauksissa. Poikkeuksen ovat muodostaneet pronominit, sillä on aivan epäämätöntä, että ne ovat voineet esiintyä joko pääsanansa edessä tai jäljessä. On kuitenkin syytä välttää tässä yhteydessä pääsana-nimitystä, on tarkoituksenmukaisempaa puhua sanasta, johon pronominin voidaan katsoa meidän kannaltamme määritteen luontoisena liittyneen. Possessiivisuffiksien ja persoonapäätteiden synty ei olisi muuten lainkaan ymmärrettävissä, jollemme olettaisi, että pronominien käyttäytyminen sanajärjestysseikoissa on ollut eräissä tapauksissa toisenlainen kuin muiden sanojen. Nehän ovat joka tapauksessa syntyneet persoonapronomineista. Mutta myöhemmistäkin kehitysvaiheista meillä on riittäviä osoituksia siitä, että pronominien poikkeusasema on säilynyt hyvin kauan niissäkin kielissä, joissa vanha sanajärjestysprinsiippi on suurin piirtein voimassa. Mordvan kielen määräävän taivutuksen synty on tietenkin selitettävissä vain siten, että demonstratiivipronomini on sulautunut edellä käyvään sanaan, esim. t'śoraś < t'śoratśe.

Ei ole kuitenkaan syytä luulla, että pronominin paikka lauseessa olisi ollut mielivaltainen. Olen päätynyt siihen, että vain painottomaksi käsitettäyä pronomini on esiintynyt pääsanan jäljessä, kun sen sijaan painollisena on ollut ennen pääsanaa. Tällaiseen on tietysti ollut omat syynsä. Voi hyvinkin olla mahdollista, että eräät 
kielen rytmilliset seikat ovat näytelleet osaa asiassa. Pronominit ovat alkuaan uralilaisissa kielissä olleet säännöllisesti yksitavuisia, toisin kuin muut sanat, joiden vartalo on ollut kaksitavuinen. Kun pääpaino on ollut" ensi tavulla, ei pronomini voinut liittyä seuráavaan sanaan niin kiinteästi; että olisi syntynyt kielen normaalien mällien mukainen rytmillinen muodoste. Sanottiin siis se-poika, koskà poika sanassa pääpaino oli säilytettävä ensi tavulla. Sen sijaan sopi rytmillisiin kuvioihin poika_se, jossa pronomini saattoi varsin kiinteästi liittyä edellä käyvään sanaan. Tämä taas teki kaikki kulumisilmiöt, vieläpä täydellisen súlautumisenkin mahdolliseksi ja nïn pronomini menetti nimenomaan tässä asemassa itsenäisyytensä. Sanan edessä pronomini taas säilytti itsenäisen asemansa eikä sevoinut olla sulautumisuhan alaisena. Tällaisten painotusseikkojen lisäksi on tietysti otettava huomioon myös pronominien erikoinen merkitysfunktio, mikä on saattanut näytellä ratkaisevaa osaa näissä. sanajärjestyssuhteissa. On ilmeistä, että pronomini havainnollisessa puheympäristössä on senlaatuinen, että se itsessään ja ainakin viittauksen myötäilemänä täysin selvittää mistä on kysymys. Näin ollen tuskinpa sellaisissa yhtymissä kuin tämä poika, tuo koira pronomini on ollut mikään määrite. Se on ollut itsenäinen pääsana. Sitä seuraava substantiivi on ollut eräänlainen täyte, lisä, ja niin ollen oikeastaan appositio. Pronomini on tietysti saanut itsenäisenä ollessaan lauseen vaatimat taivutuspäätteet ja samoin useimmiten sitä seuraava appositio. Mutta pronominia seuraava täydentävä ja selittävä substantiivi on voinut olla muussakin sijassa, jolloin se ehkä lausekokonaisuuden kannalta katsottuna on ollut pikemminkin alkuaan adverbiaalin kuin apposition luontoinen. On merkille pantavaa, että sellaiset tavalliset inkongruenssin tapaukset kuin tällä puolen, samalla kertaa tulevat nimenomaan kysymykseen juuri pronominien yhteydessä. Jos taas pronomini on seurannut substantiivia, niin sen tehtävä on ollut ikään kuin viittauksenomaisesti varmistaa, että kuulija todella tietää, mikä käytetyn substantiivin tarkoite on. Tällöin pronomini puolestaan on ollut lisä eikä varsinainen itsenäinen osa lauseessa.

Kun siis joskus esisuomessa on sanottu tänä kotana, niin kysymyksessä on ollut pääsanana esiintyneen pronominin ja sen apposition kongruenssi. Kun substantiivien taivutuksessa ns. sisäiset paikallissijat monissa funktioissa syrjäyttivät vanhàt paikallissijat, niin 
on ilmeistä, että pronomineja tämä ei aluksi koskenutkaan, vaan ne pysyivät vanhalla kannalla. Tästähän ovat suomen siinä ja siitä todisteena. Mutta lapin kielessä tuli vähitellen syntagmasta tänä

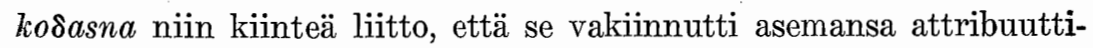
konstruktiona. Tällöin saattoi substantiivisesti käytettyihin pronomineihin liittyä jo tavalliset substantiivin päätteet ilman että se olisi enää muuttanut attribuuttikonstruktiota.

Lapissa ei kongruenssikehitys tämän pitemmälle ennättänytkään. Ruijanlapissa se yksikössä alkoi päinvastoin purkaantua. Mitä suomeen tulee, niin pitäisin selvänä, että kongruenssin lähtökohta on ollut suunnilleen samanlainen kuin lapissa. Onko niin täydellisen kongruenssin kehittyminen kuin mikä suomessa tavataan, voinut syntyä kokonaan tältä pohjalta, on tietysti kysynns, johon on toistaiseksi vaikea täsmällistä vastausta antaa. On hyvin mahdollista, että jatkuvaan kehitykseen on vieras vaikutuskin myötävaikuttanut. Mutta on kuitenkin eräitä seikkoja, jotka on nähdäkseni otettava huomioon. Possessiivisuffiksin puutteen attribuuttiosasta voi mielestäni erittäin hyvin selittää niin, että pronomineihin se ei hevin olisi voinut liittyäkään. Jos kongruenssi olisi yleistynyt pronominitapauksista adjektiiveihin, olisi possessiivisuffiksin puute siis varsin ymmärrettävää. Pronomineista ja pronominaaleista on hyvin lyhyt matka adjektiiveihin (vrt. millä, millaisella porolla? - suurella porolla).

Edelleen on muistettava, että kantasuomessa on paikallissijojen systeemi rikastunut sillä tavalla, että ns. ulkoiset paikallissijat ovat kehittyneet varsinaisiksi kaasuksiksi. Tätä kehitystä ei lappi, niin kuin ei myöskään mordva, tunne. On mahdollista, että ullkoisten

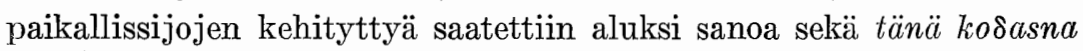

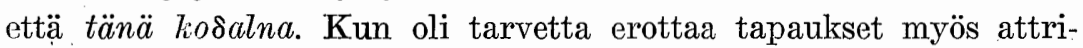
buuttiosassa toisistaan, saattoivat ensinnä ulkoisten paikallissijojen päätteet tunkeutua attribuuttiin. Tästä olisi sitten kongruenssi voimakkaasti voinut laajentua myös adjektiivit käsittäväksi.

Panvo Ravila: Die Entstehung der Kongruenz des Adjektivattributs im Finnischen

Der Aufsatz wird demnächst in erweiterter Fassung deutsch in den Publikationen der Finnisch-ugrischen Gesellschaft erscheinen. 